\title{
Evaluation of pulping therapy in deciduous teeth using chlorhephenicol tetracycline and Zinc oxide
}

\author{
Avaliação da terapia pulpar em dentes decíduos com uso \\ da pasta cloranfenicol tetraciclina e óxido de Zinco
}

\author{
Gisele Fernandes DIAS1 iD https://orcid.org/0000-0002-6766-2610 \\ Juciane TRAMONTIN1 1 iD https://orcid.org/0000-0001-7810-5337 \\ Priscila Pelexate dos SANTOS ${ }^{1}$ iD https://orcid.org/0000-0001-8261-8696 \\ Fernando ROSSI ${ }^{1}$ iD https://orcid.org/0000-0003-1506-3357 \\ Mylena RIGONI1 iD https://orcid.org/0000-0002-0748-2036
}

\begin{abstract}
The technique using CTZ paste (chloramphenicol, tetracycline, and zinc oxide-eugenol) in the endodontic treatment of deciduous teeth is easy to perform and requires a single session, which is an advantage with child patients. The inexistence of clinical protocols with the use of CTZ and the multifactorial endodontic repair process in deciduous teeth evidence the need for research on the subject. This study aimed to suggest a clinical protocol model for the systematization and standardization of the endodontic treatment of deciduous teeth using CTZ paste. In the case report presented, after pulp therapy, clinical-radiographical follow-up was conducted after 30, 60 , 90 and 180 days. It was concluded that using CTZ paste is a simple, viable, and satisfactory alternative. Future clinical studies are needed regarding CTZ use in child clinic with strong scientific evidence.
\end{abstract}

Indexing terms: Endodontics. Pediatric dentistry. Tooths, deciduous.

\section{RESUMO}

A técnica com pasta CTZ (cloranfenicol, tetraciclina e óxido de zinco-eugenol) no tratamento endodôntico de dentes decíduos é de fácil execução e requer sessão única, o que é uma vantagem em pacientes infantis. A inexistência de protocolos clínicos com o uso do CTZ e do processo de reparo endodôntico em dentes decíduos evidencia a necessidade de pesquisas sobre o assunto. Este estudo teve como objetivo sugerir um modelo de protocolo clínico para a sistematização e padronização do tratamento endodôntico de dentes decíduos com a pasta CTZ. No relato de caso apresentado, após a terapia pulpar, o acompanhamento clínico-radiográfico foi realizado após 30, 60, 90 e 180 dias. Concluiu-se que o uso da pasta CTZ é uma alternativa simples, viável e satisfatória. Futuros estudos clínicos são necessários a respeito do uso de CTZ em clínica infantil com fortes evidências científicas.

Termos de indexação: Endodontia. Odontologia pediátrica. Dente decíduo.

\footnotetext{
$\checkmark \nabla v$

1 Universidade Estadual de Ponta Grossa, Departamento de Odontologia. Av. General Carlos Cavalcanti, 4748, Uvaranas, 84030-000, Ponta Grossa, PR, Brasil. Correspondence to: PP SANTOS. E-mail: <pripelexate@gmail.com>.

$\boldsymbol{\nabla} \boldsymbol{\nabla} \boldsymbol{v}$

How to cite this article

Dias GF, Tramontin J, Santos PP, Rossi F, Rigoni M. Evaluation of pulping therapy in deciduous teeth using chlorhephenicol tetracycline and Zinc oxide. RGO, Rev Gaúch Odontol. 2021;69:e20210049. http://dx.doi.org/10.1590/1981-863720210004920200008
} 


\section{INTRODUCTION}

The premature loss of deciduous teeth can lead to malocclusion, in addition to functional and aesthetical problems [1]. The primary dentition is essential to maintain arch length, chewing, speech development, and aesthetics [2]. The intact preservation of deciduous teeth, through preserving their vitality until the natural time for exfoliation, until their permanent successors erupt, is paramount to maintain arch integrity $[1,2]$.

The conventional endodontic technique adopted in pediatric dentistry poses countless challenges concerning child patients. Public dental services oftentimes cannot offer the conventional endodontic technique for deciduous teeth - with radiographs and chemomechanical preparations - due to the great amount of clinical time it takes. The deciduous teeth endodontic procedure has been described as complex because of its anatomical singularities, the topography of the root canals, relation to adjacent structures, the biological cycle of the tooth, and pulp disease etiological factors $[3,4]$. The characteristics of deciduous teeth root canals make them difficult to be effectively manipulated during endodontic treatment. Therefore, using filling paste with antimicrobial properties is one of the most important aspects of such successful treatments $[4,5]$.

In 1964, Cappiello recommended that endodontic paste made with chloramphenicol, tetracycline and zinc oxide-eugenol be used to treat deciduous teeth with pulp necrosis [6]. The use of use CTZ paste (chloramphenicol, tetracycline, and zinc oxide-eugenol) is a simple, single-session technique with antibacterial properties, which stabilizes bone reabsorption without causing involved tissues to be sensitive
[5]. Moreover, the technique does not require root canal instrumentation prior or posterior to disinfection, which gives it a clinical advantage when treating a noncooperative child patient [4]. However, longevity studies are needed to verify the clinical success of the treatment [7].

Furthermore, the success of endodontic therapy in deciduous teeth depends on the patient's organic response, maximal removal of necrosed tissue, and action of medications placed in the canals to fill and disinfect them [8]. It is significant that, in all the child clinic endodontic procedures, every technique be discerningly performed, in which each step contributes to a successful treatment. Nevertheless, many pediatric dentists and clinicians blame their lack of technical criteria on the child's behavior and the inner anatomical characteristics of the deciduous teeth $[4,9]$.

Based on the abovementioned considerations, this paper aimed to describe a clinical case and suggest a protocol for the use of CTZ in child clinic to optimize the treatment, furnishing quality and diminishing clinical time, based on current literature scientific evidence.

\section{CASE REPORT}

A 4-year-old leukoderma male patient attended the Child Integrated Multidisciplinary Clinic of the State University of Ponta Grossa, Brazil, accompanied by an adult responsible for him. He did not present systemic alterations, was not making continuous use of medications, and had no signs of allergies. In clinical examination, teeth 51 and 61 (figure 1) presented extensive crown destruction associated with intraoral fistulous abscesses. Tooth 55
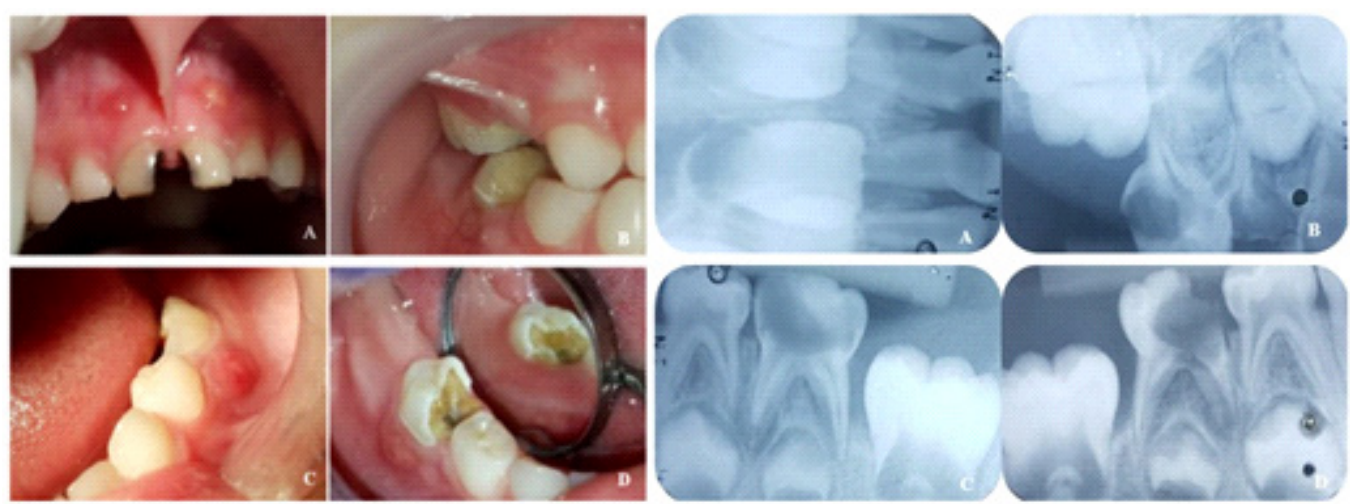

Figure 1. Clinical-radiographical presentation of dental elements. A) Teeth 51, 61; B) Tooth 55; C) Tooth 75; D) Tooth 85. 
(figure 1) had extensive carious lesions, with no clinical sign of pulp involvement. Teeth 52, 53, 62, 63, 64, 65, $71,72,73,81,82,83$ and 84 were healthy, and 54 had an indication of extraction. Teeth 75 and 85 had clinical evidence of carious lesions with pulp involvement and presence of abscess (figure 1).

Periapical radiographs were taken from the anterior upper region of teeth 51, 61, 75 and 85 (figure 1), whose crown was extensively destroyed, with periapical radiolucency. Tooth 55 radiographically presented extensive carious lesion with pulp involvement, whose diagnosis was compatible with necessary pulp therapy. CTZ protocol took place in single sessions - teeth 51 and 61 were treated in one session, and teeth 55, 75 and 85 in separate sessions. The CTZ technique was performed in the following sequence:

1. Short-needle anesthesia of the region - teeth 51, 61 and 55, infiltrative anesthesia; and teeth 75 and 85 , block anesthesia - using mepivacaine at $2 \%$ with epinephrine 1:100,000 (Figure 3A);

2. Absolute isolation with a rubber dam and child Ostby frame. In teeth 51 and 61, the modified absolute isolation technique was performed, while teeth 55, 75 and 85 were isolated with clamp number 29;

3. Convenience and contour form: the root canals were accessed with a spherical diamond drill; the carious lesion was removed with low-rotation spherical drills (compatible with the size of the lesion) and dentin spoons; the pulp chamber roof was removed with high-rotation spherical drills (figure 3B), under constant irrigation. The final contour of the endodontic cavity was performed based on the inner anatomy of the pulp chambers and the root canals access curvature. In the posterior teeth, the cusp in the entrance to the canals was removed with an Endo-Z $21 \mathrm{~mm}$ drill. The crown pulp was removed with dentin spoons, giving access to the opening of the root canals, and relieving the bleeding;

4. Irrigation with sodium chloride at $0.9 \%$ using a $5 \mathrm{ml}$ disposable syringe and disposable 20x0.55 (24G 3/4) needle, and aspiration with a disposable endodontic aspirator (figure 3C);

5. Drying of the pulp chamber with sterile cotton balls to control bleeding;

6. Manipulation of CTZ antibiotic paste (powder formula with $1 \mathrm{~g}$ tetracycline, $1 \mathrm{~g}$ chloramphenicol, and 2 $\mathrm{g}$ zinc oxide, mixed with liquid eugenol in the proportion of 1: 1:2) in a glass plate with a number-24 manipulating spatula. Filling the root canal entrance with paste (Figure 3D), using the Capillary tip attached to a Luer Look 1.2 $\mathrm{ml}$ plastic syringe, and then applying pressure with sterile cotton balls to compress the paste into the root canal;

7. Sealing the root canal entrance with a thin layer of gutta-percha in a heated stick aided by pluggers (figure $4 A)$;

8. Filling the cavity with photopolymerized glass ionomer cement (figure 4B). Photopolymerization for 40 seconds (figure 4C).

9. Final radiograph with child periapical film positioners and manual development.

10. Clinical-radiographical follow-up: 30,90 and 180 days. The treatment stages are described in figures 2, $3,4,5$, and 6 .

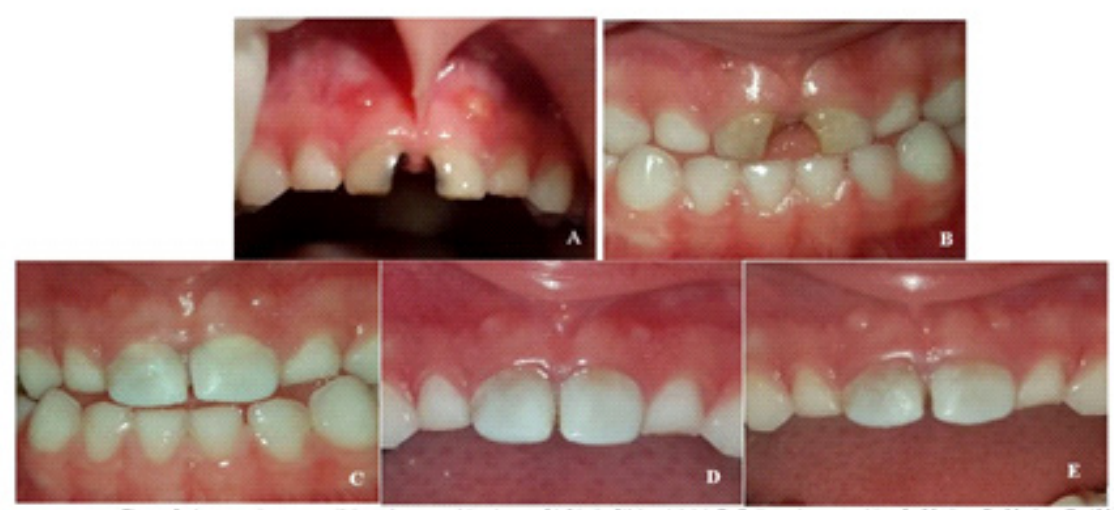

Figure 2. Postoperative clinical follow-up - teeth 51 and 61. A) Initial clinical; B) 7 postoperative days; C) 30 days; D) 90 days; E) 180 days. 


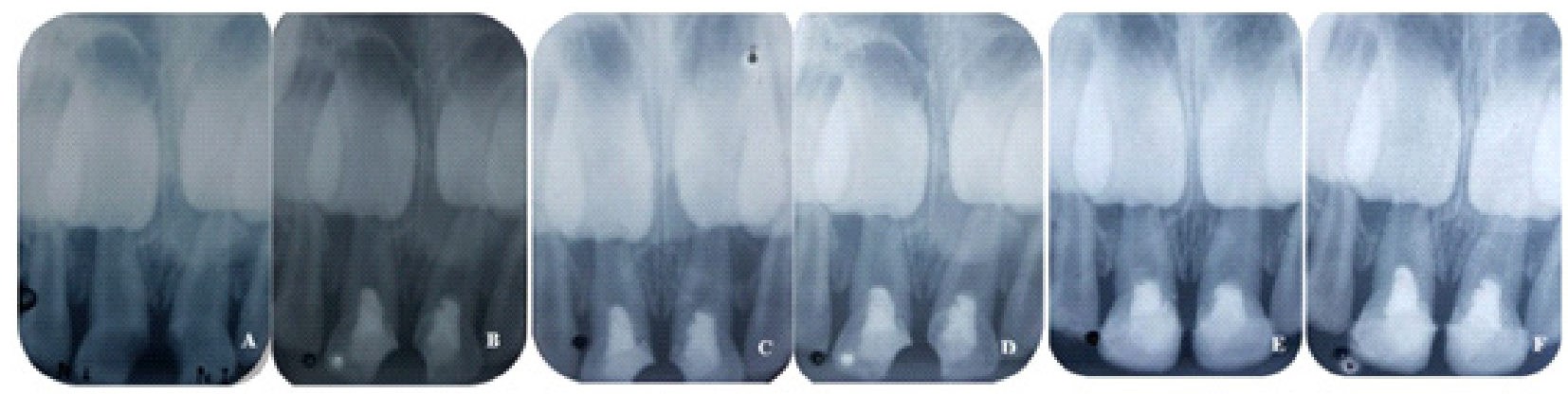

Figure 3. Radiographical follow-up - teeth 51 and 61. A) Initial clinical; B) 7 postoperative days; C) 30 days; D: 90 days; E) 180 days.
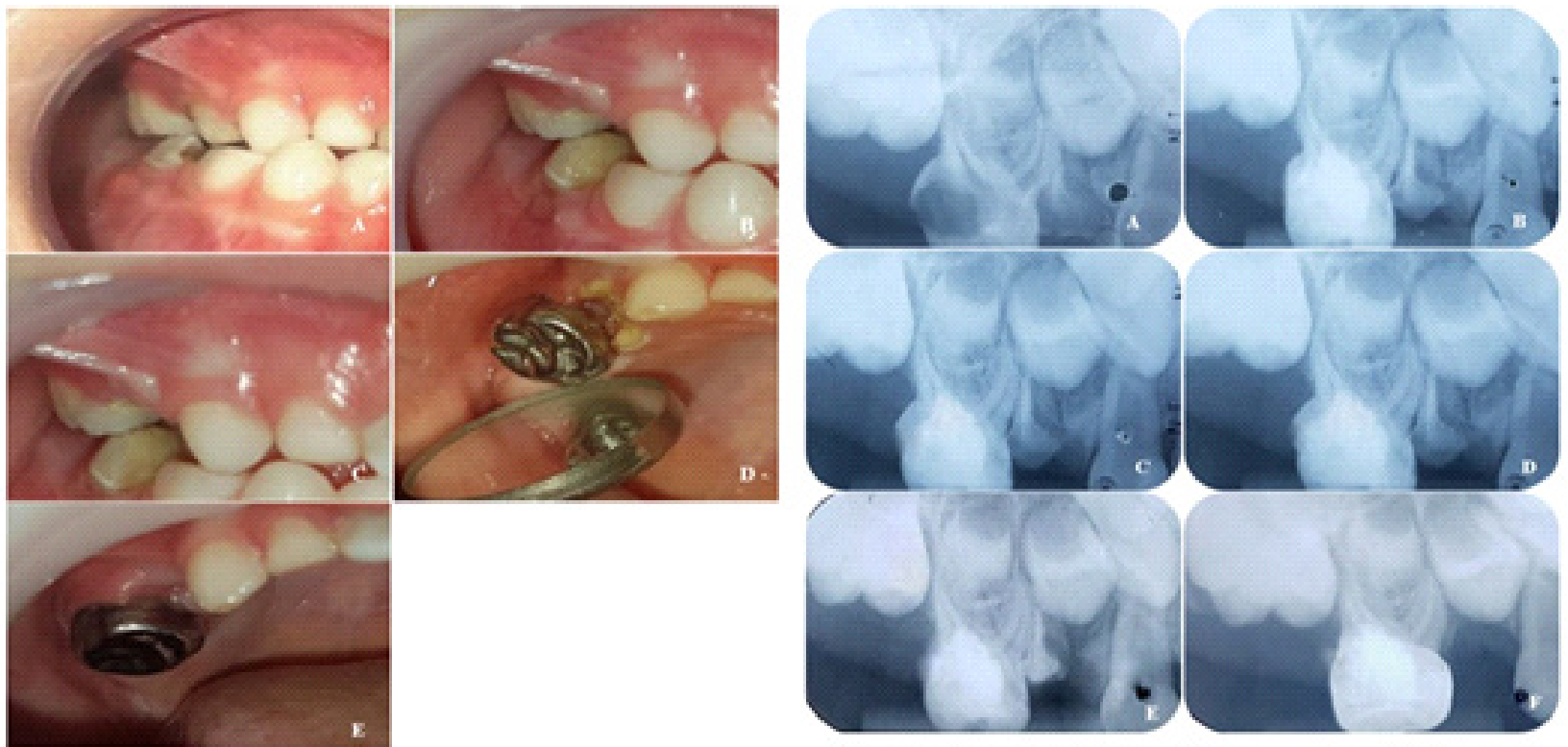

Figure 4. Clinical-radiographical follow-up - tooth 55. A) Initial clinical; B) 7 postoperative days; C) 30 days; D) 90 days; E) 180 days.
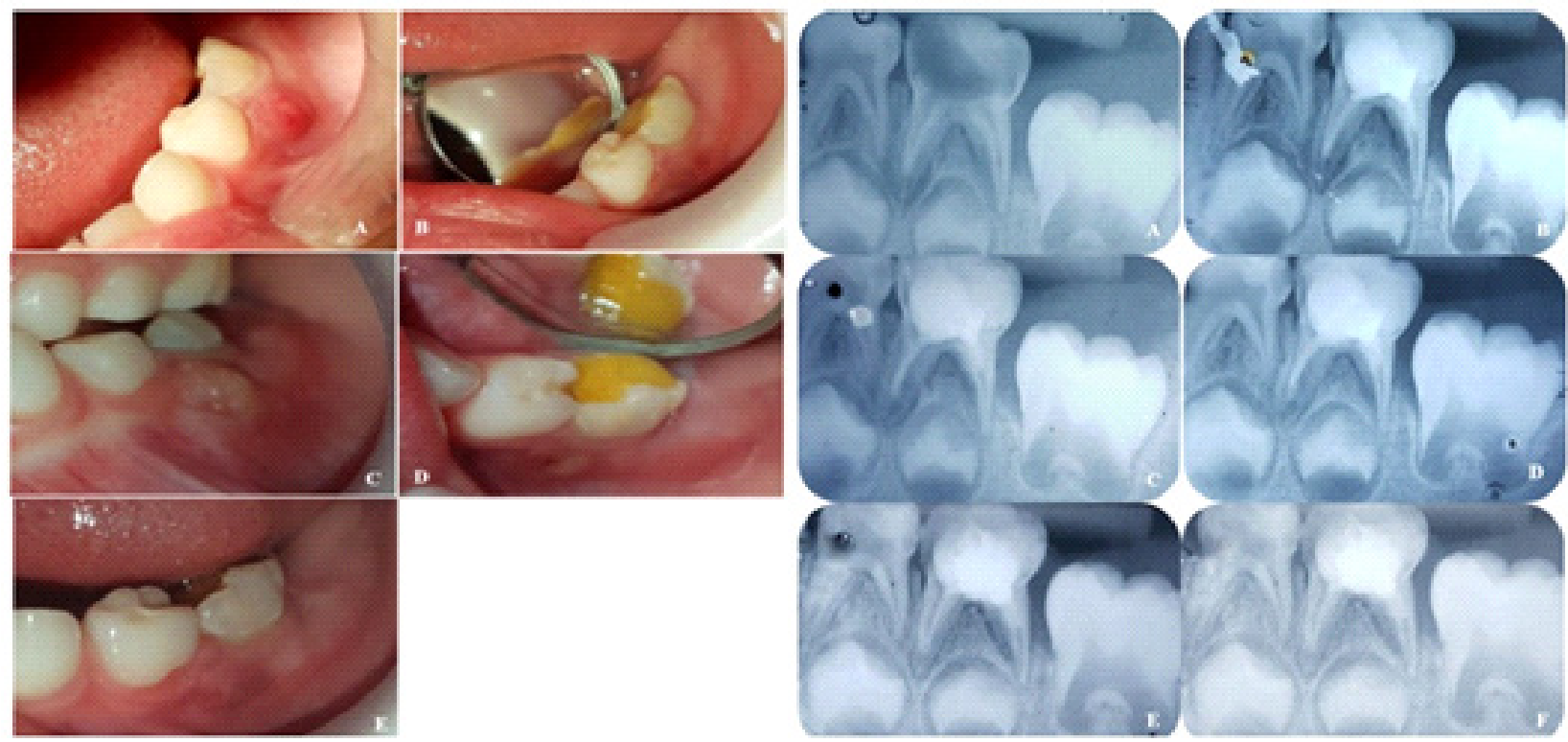

Figure 5. Clinical-radiographical follow-up - tooth 75. A) Initial clinical; B) 7 postoperative days; C) 30 days; D) 90 days; E) 180 days. 

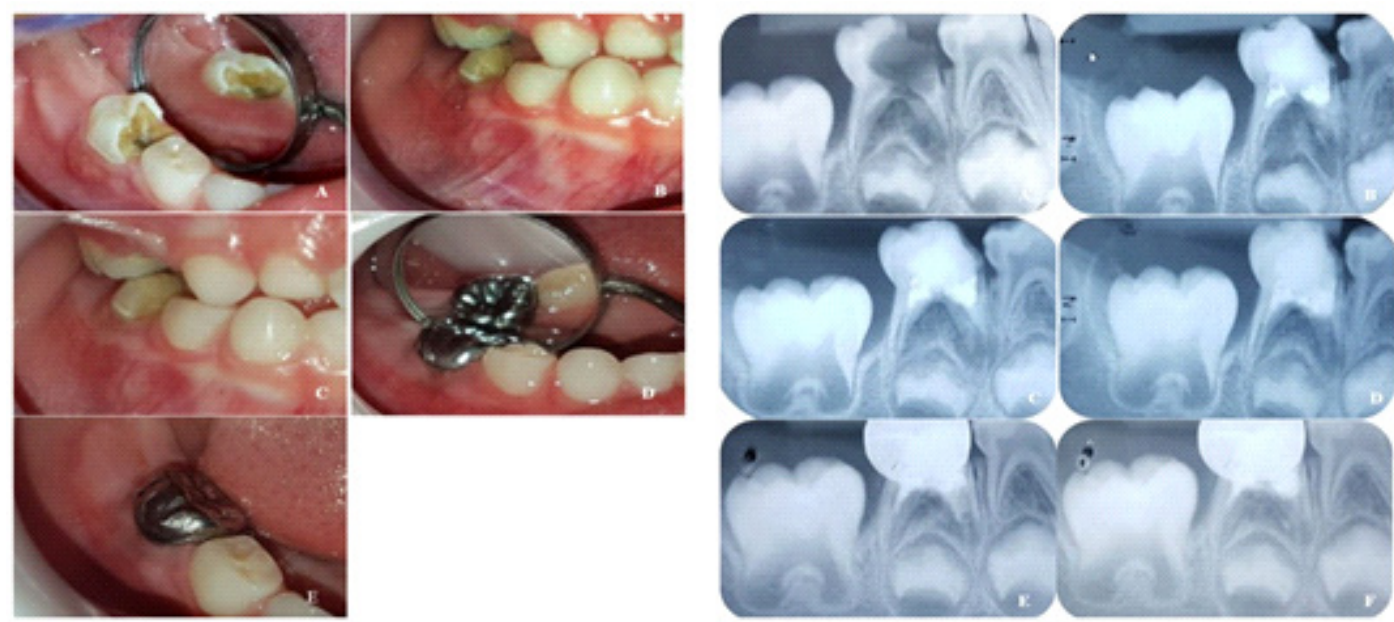

Figure 6. Clinical-radiographical follow-up - tooth 85. A) Initial clinical; B) 7 postoperative days; C) 30 days; D) 90 days; E) 180 days.

After concluding pulp therapy, teeth 51 and 61 were rehabilitated with celluloid matrix crowns. The arches were molded with stock trays and condensation silicone. After leaking and affixing the plaster, the matrices were adapted on the model teeth; they were cut with fine point scissors for best cervical adaptation. A hole was opened on the palatine side of the celluloid matrix aided by the tip of the exploring probe through which to drain the excessive resinous material before fully inserting the resinous material into the matrix.

The dental remnant was prepared to be restored with compound resin, through conditioning with phosphoric acid at 37\% for 15 seconds in enamel and 7.5 seconds in dentin, washing and brief drying. Then, Ambar Universal (FGM, Joinville, Brazil) adhesive tape was applied with friction movements, light air jet, a new layer of adhesive, and lastly 20-second photopolymerization. As the dental remnant's color was altered due to pulp necrosis, it was decided to use opaque resin as a backing to mask the difference in color and a superficial layer of translucid resin. The matrices were positioned aligned with the other dental elements; the excessive resinous material was removed with a resin spatula and then photopolymerized for 60 seconds on the vestibular side and another 60 seconds on the palatine side. The celluloid matrices were removed with the exploring probe, and then the teeth received an additional 30-second photopolymerization on each side to ensure the complete polymerization of the compound resin. The cervical region was finished with 2200 flameshaped end conical diamond tip and polished with abrasive rubber and polishing paste.
Teeth 85 and 55 were restored with steel crowns. The dental remnant was prepared first by reducing the occlusion with a conical body diamond drill (4138), wearing it approximately $1 \mathrm{~mm}$ to reach the cervical-occlusal height of the crown. Then, a conical-body diamond drill (2200) was used to remove the mesial and distal proximal points of contact, in the vestibular-lingual direction to furnish the necessary space to fit the steel crowns. The vestibular and lingual sides were also a little worn, and the sharp angles were smoothed with the rounded end conical drill (2135). The size of the steel crown was identified with a dry-point compass used to measure the mesiodistal length of the dental remnant. After the selection, the crowns were tested in place to confirm the measure previously obtained and verify the established occlusal relation. The crowns were fitted with large-diameter abrasive stones in the cervical region to provide the precise fitting preserving the region's gum tissue. The cervical fitting was performed aided by 114 and 417 dental pliers, to increase mechanical retention of the crowns and favor cervical fitting. Lastly, the steel crown was cleaned on the inside and outside with gauze damped with $70 \%$ alcohol, to remove any residue.

To cement the crown, it was opted to use Maxxion C (FGM, Joinville, Santa Catarina, Brasil) glass ionomer cement. The material was manipulated with viscous consistency and inserted into the crown and pressed into place with finger pressure; then, the patient was asked to occlude. The cementing took place with relative isolation. The excessive cement was removed; it was done with an exploring probe on the outer portion, and dental floss in 
the proximal faces. The occlusion was clinically evaluated, not presenting any significant alterations.

To evaluate the clinical effectiveness of the endodontic treatment with CTZ paste, the following parameters were considered: spontaneous pain, sensibility to percussion or palpation, presence of a fistula, fistula scar, change in color, purulent exudate, cellulitis, pathological mobility, lymphadenopathy of the related region. Radiographically: the presence of periapical or furcation radiolucency, pathological internal or external root reabsorption, widening of the periodontal area, calcification of the pulp canal.

Radiographically, teeth 51 and 61 presented extensive crown destruction with pulp chamber involvement. Immediately after the therapy, the presence of the material in the root canal opening was perceived. In radiographical follow-up after seven days, there were no alterations; after 30 days of follow-up, periapical radiolucency was noticeably decreasing (figure 5D); after 90 and 180 days, the lesion continued to regress.

In initial clinical examination, teeth 51 and 61 presented extensive crown destruction with associated fistulous abscesses. Seven days after pulp therapies with CTZ paste, these lesions presented clinical-radiographical regression, initial scarring of the fistulae and absence of painful symptomatology. After 30 days of follow-up, the teeth had been rehabilitated, using celluloid and compound resin crowns; after 90 and 180 days of clinical follow-up, total regression of the infectious process, scarring of the fistulae and absence of painful symptomatology were verified.

Teeth 75 presented extensive crown destruction with pulp inner chamber involvement, periapical radiolucency, and fistulous abscess. At the end of the pulp therapy, the opening of the root canals was filled with CTZ paste. After 30 days, periapical radiolucency was noticeably decreasing, which continued after both 90 and 180 days. The lesion had fully regressed seven days after pulp therapy with CTZ paste. Ninety days after initial treatment there was clinical regression of the lesion; and after 180 days, the tissues were normal, not presenting any painful symptomatology.

Initially, in the radiographical examination, tooth 85 presented extensive crown destruction reaching into the pulp inner chamber, associated with fistulous abscess. After 30 days of follow-up, significant regression of periapical translucency was observed, which continued in the radiographical follow-ups after 90 and 180 days. Seven days after pulp therapy, the pain was absent, and the abscess was regressing. After 30 days of followup, the tissue was normal. After 90 days, tooth 85 was rehabilitated through a steel crown. After 180 days, the tissue continued presenting normality and the absence of painful symptomatology.

Initially, in tooth 55, a wide radiolucent image was seen affecting the inner part of the pulp chamber, indicating the need for endodontic treatment. From seven to 180 days of follow-up, the periapical region remained unaltered. Clinically, tooth 55 presented extensive carious lesions. After pulp therapy, the lesion was treated with glass ionomer cement for photopolymerized restoration. Seven days after pulp therapy, the tissues remained normal, with no clinical symptomatology. After 90 days, the tooth was rehabilitated with a steel crown. After 180 days of followup, the tooth continued clinically unaltered and with no painful symptomatology.

\section{DISCUSSION}

In teeth 51, 61, 75, 85 and 55, the success of the endodontic treatment was clinically and radiographically evident, as periapical and interradicular translucency regressed. Along with the clinical characteristics, the teeth were asymptomatic, with no abscess, no pathological mobility, no sensitivity to percussion and palpation, and the fistulae were scarred.

The LSTR (Lesion Sterilization and Tissue Repair) is the repairment through the host's natural defense mechanisms, in which the principle is to sterilize the canals and the pulp chamber with antibiotic medications to provide the means for the damaged tissue to be repaired through its own mechanisms $[8,9]$. The CTZ follows that principle, as it contains wide-spectrum antibiotics $[10,11]$. The endodontic treatment with this paste is favored in deciduous teeth due to the permeability of the pulp chamber floor, accessory canals, and porosities; also, the likely communication between the pulp tissue and the periodontal tissues offer the permeability in this region's components $[8,9,12]$.

There is a disadvantage regarding tetracycline as a component of the CTZ paste: when it is inserted into the pulp chamber, there is the risk of it pigmenting the 
crown on the deciduous teeth after the treatment $[12,13]$. Hence, it is considered unaesthetic, making its use difficult in anterior regions. Thus, the rehabilitation must seek to minimize the effect, being careful when inserting the material and removing its excesses while filling the root canals $[12,13]$ Despite being a successful technique, there is a fear of using the material because of the risk of the tetracycline causing enamel stains and hypoplasia on the succeeding permanent tooth $[5,6,12,13]$. Nevertheless, enamel hypoplasia can be a consequence of systemic, traumatic, environmental or genetic events that take place while the teeth are developing, which interferes with the normal formation of the enamel matrix, as the ameloblasts are among the most sensitive cell groups in the body to the metabolic function $[5,14]$. Therefore, it cannot be emphatically stated that CTZ paste causes enamel hypoplasia in the succeeding tooth.

Among the treatments conducted in this study, one of the teeth presented a clinical intercurrence, as its abscess reappeared after 30 days; however, the same element radiographically demonstrated decreased periapical radiolucency, corroborating the clinical results highlighted in the literature [15], which presented final rate of $81 \%$ of clinical success at the end of the study. Such a result does not mean the material was unsuccessful at all, as most radiographical signs demonstrated that there was bone neoformation in the interradicular region. Using the CTZ paste contributed to the maintain the deciduous teeth in the dental arch, to complete its life cycle, avoiding extractions and the harm caused by the absence of a deciduous tooth $[14,15]$. The endodontic treatment with CTZ paste is considered an alternative for the public service, when it is not possible to perform the conventional treatment or when space maintainers are placed. These variations reported in the success rates can be attributed to differences in sample selection, evaluation criteria, and techniques employed $[8,13,15]$.

After 90 and 180 days, teeth 51,61, 55 and 85 did not present clinical alterations or painful symptomatology, characterizing the clinical-radiographical success of the CTZ paste in the time of clinical follow-up. The CTZ paste was successfully used, both in necrotic teeth pulpotomies and in living teeth $[8,13,15]$. Although treatment with chloramphenicol, tetracycline, and zinc oxide-eugenol has shown comparable and acceptable both clinical and radiographical results, further studies with larger sample sizes, longer follow-up periods, and similar methodologies are still necessary $[7,16]$. Furthermore, investigations are also needed to understand the periapical tissues' reaction to drugs, as well as the amount of drug absorption in the systemic circulation. Ultrastructural, histological, and microinfiltration studies would be useful to determine CTZ paste adequacy $[8,9,15,16]$.

CTZ paste proved to be a viable alternative to be used in endodontic treatment of deciduous teeth, with satisfactory results in postoperative follow-up. Use of CTZ paste validated clinical and radiographical effectiveness in all treated teeth in 180-day follow-up, thus providing clinical means to maintain deciduous teeth in the oral cavity for them to fulfill the required physiological cycle. The adequate cavity sealing and the immediate increase of vertical dimension using steel crowns can be considered safe and applicable in child clinic. The CTZ paste use technique in patients with impaired pulp was considered easy to perform, with short clinical time, and absence of discomfort to the child patient. Nonetheless, there were limitations, as the scarcity of conclusive literature on the subject, with a great part of the articles coming from case reports. There are few longitudinal clinical trial articles to contribute to clinical evidence on the use of CTZ.

\section{CONCLUSION}

The use of CTZ paste was shown to be clinically and radiographically effective in all treated teeth during a 180-day follow-up, in order to provide clinical conditions for the maintenance of deciduous teeth in the oral cavity and to fulfill the physiological cycle. This suggests that endodontic treatment with CTZ paste is an alternative in the public network, in cases where it is not possible to carry out conventional endodontic treatment, or the placement of space maintainers. However, limitations were found, such as the scarce conclusive literature on the subject, most of the articles from case reports, scarcity of longitudinal clinical trial articles to contribute to clinical evidence of the use of CTZ.

\section{Collaborators}

GF DIAS participated in the study and its specific contribution is described below: research design and design, data analysis and interpretation statistical analysis, writing the manuscript and critical review of the manuscript for important intellectual content. J TRAMONTIN and PP SANTOS participated 
in the study and its specific contribution is described below: obtaining data, data analysis and interpretation, writing the manuscript. F ROSSI and M RIGONI participated in the study and its specific contribution is described below: obtaining data, data analysis and interpretation.

\section{REFERENCES}

1. Parisay I, Ghoddusi J, Forghani M. A review on vital pulp therapy in primary teeth. Iran Endod J. 2015;10(1):6-15.

2. Oliveira MAC, Costa LRRS. Desempenho clínico de pulpotomias com pasta CTZ em molares decícuos: estudo retrospectivo. Rev Odontol Brasil Central. 2010;15(40). Disponível em: <https://www.robrac.org.br/seer/index.php/ ROBRAC/article/view/74>.

3. Barr ES, Flaitz CM, Hicks MJ. A retrospective radiographic evaluation of primary molars. Pediatr Dent. 1991;13(1):4-9.

4. Denari W. É possível tratar dentes decíduos com fístula sem instrumentação dos condutos? Rev Assoc Paul Cir Dent. 1996;50(2):186-187.

5. Sousa PM, Duarte RC, Sousa SA. Clinical and radiographic monitoring of primary teeth submitted to pulp therapy with CTZ paste. Braz Res Pediat Dent Integr Clin. 2014;14(Suppl.3):56-68. https://dx.doi.org/10.4034/PBOCl.2014.14s3.06

6. Cappiello J. Tratamientos pulpares en incisivos primarios. Rev Asoc Odontol Argent. 1964;52:138 145.

7. Moura LFAD, Lima MDM, Lima CCB, Machado JIAG, Moura MS, Carvalho PV. Endodontic Treatment of Primary Molars with Antibiotic Paste: A report of 38 cases. J Clin Pediat Dent. 2016;40(3):175-177. https://dx.doi.org/10.17796/1053-462840.3 .175

8. Takushige T, Cruz EV, Asgor MA, Hoshino E. Endodontic treatment of primary teeth using a combination of antibacterial drugs. Int Endod J. 2004;37:132 138.

9. Ando N, Hoshino E. Predominant obligate anaerobes invading the deep layers of root canal dentine. Int Endodontic J. 1990;23:20-27.
10. Luengo J, Ramos A, Hernandez M, Diaz C, Carlos L, Toscano I. Clinical and radiographic effectiveness of antibiotic paste CTZ in primary molars pulpotomy. Ramdomized Controlled Clinical Trial. Int J Odontostomat. 2016;10(3):425-431. https://dx.doi. org/10.17796/1053-4625-43.1.4

11. Reis BS, Barbosa CCN, Soares LC, Brum SC, Barbosa OLCB. In vitro analysis of antimicrobial activity of CTZ binder used as material plug in deciduous teeth pulp. Rev Pró-Uni. 2016;7(3):39-42.

12. Lima CCB, Conde Junior AM, Rizzo MS, Moura RD, Moura MS, Lima MDM, et al. Biocompatibility of root filling pastes used in primary teeth. Int Endodontic J. 2015;48:405-416. https://dx.doi.org/10.1111/iej.12328

13. Núñez DG, Quiroz PT, Torrez CL, Ruiz DC. Non instrumented endodontic technique using CTZ paste. Rev Estomat. 2010;18(2):27-32. https://dx.doi.org/10.25100/re.v18i2.5715

14. Santos Junior VE, Alencar Filho AV, Leite ACGL, Rosenblatt A. Is There an association between enamel stains in premolars and endodontic treatment of their primary molar predecessors? Pesq Bras Odontoped Clin Integr. 2013;13(1):17-21. https:// dx.doi.org/10.4034/PBOCI.2013.131.03

15. Lokade A, Thakur S, Singhal P, Chauhan D, Jayam C. Comparative evaluation of clinical and radiographic success of three different lesion sterilization and tissue repair techniques as treatment options in primary molars requiring pulpectomy: An in vivo study. J Indian Soc Pedod Prev Dent. 2019;37(2):185-191. https://dx.doi.org/10.4103/JISPPD.JISPPD_6_19

16. Luengo J, Jiménez SA, Medrano LEC, García IT, Álvarez MA. Clinical and Radiographic Evaluation of Formocresol and Chloramphenicol, Tetracycline and Zinc Oxide-Eugenol Antibiotic Paste in Primary Teeth Pulpotomies: 24 month follow up. J Clin Pediatr Dent. 2019;43(1):16-21. https:// dx.doi.org/10.17796/1053-4625-43.1.4

Received on: 4/2/2020 Final version resubmitted on: 17/4/2020 Approved on: 3/6/2020 